\title{
IMPLEMENTASI KEGIATAN DOA REMAJA KATOLIK (REKAT) DI PAROKI SANTO HILARIUS KLEPU
}

\author{
Oleh : \\ Ag. Efendi Darmanto, Don Bosco Karnan Ardijanto ${ }^{*}$ \\ STKIP Widya Yuwana \\ *) penulis korespondensi, modhepr@widyayuwana.ac.id
}

\begin{abstract}
Prayer was very important in Jesus' life and the saints' lives. Prayer also becomes the important need in the faithfuls' life. Prayer is a mean to fight againts the devil and the power of sin. Prayer is also an expression of faith in God. It also becomes the way of human being to always remember to God. There are some problems: what is prayer? How do the Catholic teens of St. Hilarius' Parish, Klepu pray together? What kind of benefits of praying together for the Catholic Teens in St. Hilarius' parish, Klepu? What kind of impedements in praying together that the Catholic Teens of St. Hilarius' Parish experience? The aims of this research are: to clarify the definition of prayer, to explain how the Catholic Teens of Hilarius' parish, Klepu to do their praying together, to explain the benefits of prayer together for the Catholic Teens of St. Hilarius' parish, Klepu. Finally, to identify various factors that supporting or inhibiting the practice of prayer of the Catholic Teens of St. Hilarius' parish, Klepu. This research used qualitative research methods. In this study there are 10 respondents consisting of 4 male respondents and 6 female respondents. They are between 13-15 years old. They are members of St. Hilarius' parish, Klepu. The conclusions of the research are: 1) The Catholic Teens of St. Hilarius' parish, Klepu know the understanding of prayer. 2) The Catholic Teens of St. Hilarius' parihs, Klepu already carry out prayers in certain times either personally or communal prayer in St. Hilarius' parish, Klepu. 3) The Catholic Teens of St. Hilarius' parish, Klepu understand that the benefits of communal prayer are: creating a partnership or relationship with God and friends, as well as the means to develop their personality.
\end{abstract}

Keywords: Prayer, Catholic Teenagers (REKAT), Parish of St. Hilarius Klepu.

\section{PENDAHULUAN}

Doa adalah ungkapan iman kepada Tuhan sehingga menjadi sebuah kebutuhan yang penting dalam diri manusia dan doa juga merupakan suatu cara atau jalan agar manusia selalu ingat kepada Tuhan.Sebagai orang beriman, REKAT juga harus berdoa seperti Yesus dan ibu Teresa. Terlebih lagi situasi 
REKAT yang sedang bertumbuh dan berkembang dalam menyikapi berbagai perubahan dalam diri mereka sendiri: pertumbuhan fisik, perkembangan mental, psikis, karakter, sosial dan religius. Belum lagi tantangan kehidupan modern yang ditandai dengan konsumerisme, individualisme, dan hedonisme (Widi, 2009: 52). Tentu doa diharapkan menjadi salah satu sarana untuk tetap bertahan.

Remaja Katolik di Paroki St. Hilarius Klepu secara rutin mengadakan kegiatan doa bersama pada hari Rabu jam tujuh malam (19:00 WIB). Remaja Katolik yang berjumlah delapan belas (18) orang aktif dalam kegiatan. Kegiatan bertempat di aula Paroki sebagai tempat pendampingan dan pembinaan dalam sebuah kegiatan berdoa atau berkumpul bersama dengan Pendamping Rekat.

Bertitik tolak dari permasalahan di atas, ada berbagai pertanyaan yang bisa diajukan. Sejauhmana doa bersama berperan penting dalam hidup Remaja Katolik? Doa seperti apakah yang diperlukan untuk tetap tumbuh dalam kesehariharian? Sejauhmana doa berperan penting bagi pembentukan remaja?. Mendiskripsikan sejauh mana remaja terlibat dalam hidup doa? Apa saja hambatan dan rintangan dalam menjalankan doa?. Apa manfaat doa bagi kehidupan Remaja Katolik? dari perumusan masalah tersebut, maka tujuan penelitian ini adalah menjelaskan definisi doa, menjelaskan praktek doa bersama REKAT di Paroki St. Hilarius, Klepu, menjelaskan manfaat doa bagi REKAT di Paroki St. Hilarius, Klepu, mengidentifikasi faktor-faktor mendukung/menghambat di dalam praktek doa bersama REKAT di Paroki St. Hilarius, Klepu.

\section{REMAJA KATOLIK (REKAT)}

\subsection{Definisi Remaja}

Remaja merupakan masa peralihan dari masa anak-anak menuju arah kedewasaan. Kalau digolongkan sebagai anak-anak sudah tidak sesuai lagi, tetapi bila digolongkan dengan orang dewasa juga belum sesuai. Batasan masa remaja dari berbagai ahli memang sangat bervariasi. Masa remaja adalah masa peralihan dari masa anak dengan masa dewasa yang mengalami perkembangan sesuai aspek/fungsi untuk memasuki masa dewasa (Widyaningsih, 2011: 77). Ahli psikologi memberikan pengertian tentang remaja. Para pakar tersebut memandang remaja dengan berbagai sudut pandang yang akhirnya menimbulkan beraneka ragam pengertian dan batasan tentang remaja.

Gunarsa (2008: 205) mengatakan bahwa masa remaja sebagai masa penuh gejolak, emosi, dan ketidakseimbangan yang tercakup dalam storm and stress Remaja diombang-ambingkan oleh munculnya: (1) kekecewaan dan penderitaan, (2) meningkatnya konflik, pertentangan-pertentangan, dan krisis penyesuaian diri, (3) impian dan khayalan, (4) pacaran dan percintaan, dan (5) keterasingan dari kehidupan dewasa dan norma-norma kebudayaan. 
Paus Yohanes Paulus II dalam Catechesi Tradendae art. 38, menyebutkan bahwa masa remaja sebagai satu periode kehidupan yang agung sekaligus mencantumkan bahaya. Periode tersebut dimana anak remaja menemukan dunia batinnya sendiri, tahap munculnya pertanyaan-pertanyaan yang lebih mendalam, masa mencari dalam kecemasan atau bahkan frustasi, masa kecurigaan tertentu terhadap sesama dan introspeksi yang berbahaya, dan kalanya masa pengalaman pertama kemunduran dan kekecewaan.

Dari uraian di atas, dapat disimpulkan bahwa remaja merupakan masa peralihan pertumbuhan awal hingga masa memasuki kedewasaan, dimana mereka sudah tidak dapat disebut sudah dewasa tetapi juga tidak dapat disebut anak-anak. Masa remaja mengalami perkembangan sekaligus perubahan sikap, emosi, fisik dll. Dilihat secara umum, jelas bahwa remaja adalah manusia berumur belasan tahun. Masa remaja merupakan suatu masa yang menjadi bagian dari kehidupan manusia yang di dalamnya penuh dengan dinamika kehidupan yakni masa “belajar” untuk tumbuh dan berkembang dari masa anak-anak ke arah dewasa. Dinamika kehidupan remaja ini akan sangat berpengaruh dalam pembentukan diri remaja itu sendiri.

Alfons (1987: 33-37) mengatakan bahwa usia remaja berkisar antara 12-22 tahun. Walaupun mereka dikategorikan sebagai remaja, tentu secara psikologis remaja usia 12 tahun tidak sama dengan remaja berusia 22 tahun. Oleh karena itu, masa remaja dibagi menjadi dua kelompok usia, yakni remaja usia 12-15 tahun dan remaja usia 16-22 tahun. Pada masa ini remaja berusia 12-15 tahun berbeda dengan 16-22 tahun.

Pada usia 12-15 merupakan masa awal pubertas yang belum stabil. Masa remaja adalah masa transisi antara masa kanak-kanak ke masa dewasa. Masa transisi anak remaja ditandai dengan pencarian jati dirinya seperti melawan orang tua, memiliki pendapat sendiri, memiliki perilaku yang berbeda dengan yang lainnya, dan terdapat sebuah perubahan pada dirinya menuju sebuah cita-cita yang luhur (bdk. Sarwono 2010: 72).Usia 16-22 tahun, adalah masa untuk memilahmilah antara pengalaman dan proses. Ini akan menjadi tolak ukur kedepannya. Mereka suka mencari tantangan baru terutama dalam pembentukan mental, psikis dan pola pikir menuju pendewasaan diri.

Masalah agama pada remaja menyangkut tiga hal, yaitu kesadaran beragama, pelaksanaan ajaran agama, dan tingkah laku yang sesuai dengan ajaran agama. Pertama, kesadaran beragama. Pada usia remaja, remaja mulai kritis terhadap tindakan orang dewasa yang sering bertentangan dengan keyakinan yang telah ia terima pada masa kecil. Situasi ini dapat mengakibatkan kekaburan nilai. Kedua, pelaksanaan ajaran agama. Minat dan pelaksanaan ajaran agama akan lebih mudah bila pada masa kecil remaja telah mendapat pembinaan agama yang baik (bdk. Hurlock, 1992: 130). 
Menurut Willis (2008: 68) disiplin dalam agama timbul oleh (1) pengaruh dari orangtua, (2) penanaman kesadaran iman dalam hati remaja sehingga ia merasa takut pada Allah, disamping itu tumbuh rasa kagum akan kuasa Allah dan cinta kasih Allah dan (3) pengaruh lingkungan yang taat beragama. Maka dengan ketiga masalah agama (kesadaran beragama, pelaksanaan ajaran agama, dan tingkah laku yang sesuai dengan ajaran agama) sesuai faktor pelaksanaan ajaran agama. Setiap remaja dituntut untuk menyesuaikan perilakunya dengan keinginan Tuhan. Salah satu kesukaran remaja untuk menjalankan ajaran agama dapat disebabkan oleh keyakinannya yang belum mantap pada agama yang dianutnya atau kurang mengerti (masih ikut-ikutan).

Remaja mulai kritis terhadap tindakan orang dewasa dan mencoba mengikuti keterlibatan dalam hal kerohanian. Jika semangat ini sudah berkembang dalam diri remaja, akan tampak kesungguhannya untuk beribadah, rela berkorban, bersikap toleran, dan kemauan yang kuat untuk membangun diri dan masyarakat (bdk. Willis, 2008: 68). Sikap remaja dalam beragama saat ini masih mengikut orang lain; percaya dan hanya ikut-ikutan. Hal ini biasanya dihasilkan oleh pendidikan agama secara sederhana yang didapatkan dari keluarga dan lingkungannya. Ini hanya terjadi pada masa remaja awal (Usia 12-22 Tahun). Percaya dengan kesadaran dan semangat keagamaan dimulai dengan melihat kembali masalah-masalah keagamaan yang mereka miliki sejak kecil. Mereka ingin menjalankan agama sebagai sesuatu yang baru untuk membuktikan pribadinya mampu atau bisa melakukan sendiri.

Dengan demikian, dapat disimpulkan bahwa usia remaja 12-15 tahun memiliki perbedaan dengan remaja usia 16-22 tahun. Remaja usia 12-15 tahun secara fisik mengalami masa pubertas menuju ketahap pendewasaan fisik, serta pada pola pikir. Pada usia remaja 12-15 tahun, mencoba meninggalkan masa kanak-kanakan dengan mencoba hal-hal baru yang berbeda dengan remaja usia 16-22 tahun yang bersifat kritis (serta belajar menyikapi sebuah masalah) pada sesuatu yang terjadi.Remaja usia 12-15 tahun dan remaja usia 16-22 tahun juga terdapat kesamaan. Kesamaan tersebut terletak pada pendewasaan diri. Pada usia 12-15 tahun remaja sudah mulai menerima bentuk tubuh menuju pendewasaan diri atau keutamaan mencari jati diri. Sedangkan pada usia 16-22, dia mulai mampu mengolah dan memilah-milah dari proses pendewasaan diri tersebut.

Memang saat ini perlu disadari juga bahwa hidup iman bukanlah sesuatu yang secara khusus diisi kedalam anak oleh ayah dan ibunya. Iman ini pertamatama adalah suatu anugerah Allah yang berkembang mengikuti irama hidup seseorang dan kehidupan sekitarnya. Namun perkembangan iman tidak terjadi secara otomatis, tetapi sungguh suatu buah hasil proses yang dihayati dengan seluruh kehendak bebasnya dan rahmat Tuhan. 


\subsection{Remaja Katolik}

Ciri khas utama yang membedakan Remaja Katolik dengan remaja pada umumnya ialah bahwa mereka sudah menerima Sakramen Baptis. Mereka adalah Kaum beriman Kristiani yang percaya serta ambil bagian dalam Tritugas Kristus:

"Kaum beriman Kristiani ialah mereka yang, karena melalui baptis diinkorporasi pada Kristus, dibentuk menjadi umat Allah dan karena itu dengan caranya sendiri mengambil bagian dalam tugas imami, kenabian dan rajawi Kristus, dan sesuai dengan kedudukan masing-masing, dipanggil untuk menjalankan perutusan yang dipercayakan Allah kepada Gereja untuk dilaksanakan di dunia.” (KHK kan. 204 §1).

KHK kan. $204 \S 1$ merujuk pada arah dasar seseorang manusia yakni iman. Iman merupakan bagian penting dari kaum beriman, kaum awam ikut ambil bagian dalam partisipasi Tritugas Kristus, hingga mampu berelasi dengan Gereja dalam partisipasi tugas kerasulan serta partisipasi tritugas Kristus.

Remaja dapat dikatakan Katolik bila sudah menerimakan Sakramen baptis sehingga remaja tersebut memiliki identitas sebagai umat Allah. Remaja tersebut dikatakan memiliki pengaruh dan keterlibatan sebagai kaum beriman, meskipun dalam realitanya belum sepenuhnya mampu menerapkannya dalam kehidupan menggereja dan lingkungan masyarakat. Remaja Katolik yang sudah menerima Sakramen pembaptisan memiliki konsekuensi sebagai umat Kristiani diantaranya yakni: partisipasi dalam Tritugas Kristus, menjadi warga Gereja, dan ikut dalam kerasulan Gereja.

Keuskupan Surabaya membagi Bidang Pembinaan (Formatio) yang mencakup Keluarga, BIAK, REKAT, OMK. Ardas Keuskupan Surabaya (Seri DPK 05.01.00) menjelaskan bahwa Remaja Katolik yang disingkat dengan REKAT merupakan komunitas wadah kreativitas, pengembangan, pengaderan generasi muda di lingkungan, stasi, atau paroki dalam gereja Katolik di bawah naungan Bidang Pastoral (Arah Dasar Keuskupan Surabaya, 2010-2019: 34-33).

Bidang Pembinaan (Formatio) tentang REKAT (Remaja Katolik) merupakan wadah Pastoral bagi remaja-remaja yang duduk di bangku SMP. Organisasi pastoral ini sebagai wahana pendampingan. Keuskupan Surabaya membentuk Komisi tersendiri, yang terpisah dari Komisi BIAK dan Komisi Kepemudaan, sehingga konsentrasi pembinaan iman dan pendampingan mereka lebih mendalam. Bidang Pembinaan (Formatio) berisikan unsur-unsur berkaitan dengan lima bidang Pastoral salah satunya yakni Remaja atau sering dikenal dengan sebutan REKAT (Remaja Katolik) jadi di tingkat Keuskupan, bidang pastoral remaja merupakan Komisi Kerasulan Remaja Katolik (REKAT). 


\section{PENGERTIAN DOA}

Doa adalah bagian tindakan manusia dalam persekutuan kepada Allah, dengan bercakap-cakap atau berkomunikasi. Di Katekismus Gereja Katolik (KGK art. 2567) mengatakan bahwa sebelum manusia memanggil Tuhan, terlebih dahulu Tuhanlah yang memanggil manusia. Bahkan apa bila manusia melupakan Penciptanya atau menyembunyikan (memalingkan) diri dari hadapan-Nya, namun Allah yang hidup dan benar tanpa jemu-jemunya memanggil setiap manusia untuk suatu pertemuan penuh rahasia denga-Nya di dalam doa. Dalam Kamus Besar Bahasa Indonesia, doa didefinisikan sebagai suatu permohonan, harapan, permintaan, dan pujian kepada Tuhan (KBBI, 2008).

KWI (2009: 557) mengatakan bahwa doa bersumber dari Sabda Allah yang dianugerahkan kepada manusia supaya manusia mengenal Kristus. Pengenalan akan Kristus itu merupakan tanggapan atas karunia Allah kepada manusia. Selain itu, doa juga bersumber dari Yesus Kristus, Roh Kudus, Kitab Suci dan Para Kudus (Rasul Paulus - St Teresa dari Avila). Dalam tradisi Kristen, Yesus Kristus tidak hanya diimani sebagai nabi, utusan Allah, tetapi sebagai Sang Sabda (Yoh 1: 14) dan pengantara antara Allah dan manusia (1 Tim 2: 4). Dia adalah Anak Allah. Dia juga merupakan pusat dari Tradisi sehingga Tradisi tak hanya mengenalkan Yesus Kristus saja tetapi juga meneruskan faktor kehidupan Yesus Kristus dan ajaran-Nya (KWI, 1996: 187).

Selain berpusat pada pribadi Yesus Kristus serta ajaran-Nya, Tradisi Kristen juga melihat pentingnya kehidupan umat beriman yakni Gereja yang tumbuh dan berkembang dalam doa. Oleh karena itu, Tradisi dimaknai sebagai sesuatu yang sakral dan bersifat liturgis (keterlibatan Gereja bersama Kristus) sebagai sebuah satu kesatuan antara "karya Yesus sebagai kepala atau Imam serta Tubuh-Nya, yakni Gereja itu sendiri” (bdk. KWI, 1996: 196).

Berkat merupakan tindakan Allah yang mengasihi manusia. Manusia bersatu dengan menerima sapaan langsung dari Allah. Manusia selalu berusaha dan berdoa memohon berkat dengan cara berkomunikasi kepada Allah. Sebab dalam doa terdapat suatu kekuataan yakni anugerah dari Allah kepada manusia, pertemuan ini hakikatnya dibawa oleh Roh Kudus melalui Yesus Kristus kepada Bapa. Dengan demikian, setiap orang menerima berkat (anugerah) dan dengan berdoa manusia mengenal Allah sebagai sumber segala berkat. Doa penyembahan "Proskuneo" adalah sikap pertama manusia yang mengakui diri sebagai makhluk serta mengakui bahwa Allah sebagai Sang Pencipta-Nya.

"Penyembahan adalah sikap pertama manusia, yang mengakui diri sebagai makhluk di depan Pencipta-Nya. Ia memuliakan kebesaran Tuhan yang menciptakan kita dan kemahakuasaan Penyelamat yang membebaskan kita dari yang jahat. Dalam penyembahan, roh menundukkan diri di depan "Raja kemuliaan (Mzm 24: 9-10)". Penyembahan Allah yang kudus dan yang 
harus dicintai di atas segala-galanya, memenuhi kita dengan kerendahan hati dan memberi kepercayaan teguh kepada permohonan kita “(KGK art. 2628)

Artikel tersebut menjelaskan bahwa penyembahan adalah wujud pengakuan diri manusia sebagai ciptaan sekaligus mengalami Allah pencipta. Selain itu, penyembahan sebagai pengakuan atas penyelamatan Allah. Pai (2003: 130-131) mengatakan bahwa penyembahan merupakan tindakan manusia dalam penyembahan serta menyatakan kebesaran dan kuasa-Nya yang menciptakan segala isi bumi. Penyembahan yang dikehendaki Allah adalah pemberian diri manusia seutuhnya sebagai tanggapan dari kasih Allah yang sudah lebih dahulu mengasihi manusia.

Doa Gereja diwarnai dengan sebuah harapan serta permohonan akan keselamatan. Manusia memohon pengampunan kepada Bapa dan Putra-Nya disertai dengan kerendahan hati. Doa permohonan dilukiskan sebagai permintaan dari manusia dengan meminta atau memanjatkan sesuatu doa kepada Allah. Dalam doa tersebut, manusia mengakui kelemahan dan berusaha serta berharap dengan penuh kepercayaan kepada-Nya (Flp 4: 6).

Doa syafaat adalah sebuah doa permohonan yang mengarahkan manusia untuk berdoa seperti Yesus berdoa. Yesus Kristus adalah satu-satunya pengantara yang menghubungkan semua doa Gereja kepada Allah. Dalam hal ini, manusia tidak hanya berdoa bagi dirinya sendiri melainkan memperhatikan kepentingan bersama.

"Setiap hati yang sesuai dengan kerahiman Allah, sejak Abraham, dapat membantu orang-orang lain dan memohon bagi mereka. Pada masa Gereja, doa syafaat orang Kristen mengambil bagian dalam doa syafaat setiap pendoa "tidak memperhatikan kepentingannya sendiri, tetapi kepentingan orang lain juga” (Flp 2:4) ya, ia malahan berdoa bagi mereka yang berbuat jahat terhadapnya.” (KGK art. 2635)

Artikel tersebut menjelaskan bahwa doa syafaat, dinaikkan kepada Allah dan ditunjukkan bukan untuk kepentingan pribadi melainkan untuk kepentingan bersama (orang lain) bahkan manusia berdoa juga untuk keselamatan bagi semua orang. Oleh sebab itu, orang Kristen memiliki kesatuan bersama orang-orang kudus, Roh Kudus yang tinggal di dalam hati manusia membatu atas kelemahan sesuai dengan kehendak Allah (Roma 8: 26-27).

Doa syukur merupakan ciri khas di dalam Gereja atas apa yang telah diberikan Allah untuk manusia dengan cara mensyukurinya. Dalam doa tentu tidak jarang seseorang mengucapkan kebahagiaan dan rasa syukur atas sesuatu yang telah dialami. Di dalam doa pujian, umat melambungkan doa dengan 
ekspresi kekaguman. Mereka mengungkapkan rasa syukur kepada Allah atas perbuatan-Nya. Itu pada dasarnya merupakan perbuatan Roh Kudus. Dalam Katekismus Gereja Katolik dijelaskan bahwa:

"Pujian adalah bentuk doa yang mengakui Allah secara paling langsung. Pujian mengagungkan Allah demi diri-Nya sendiri. Ia memberikan hormat kepada-Nya, bukan hanya karena perbuatan-perbuatan-Nya, melainkan karena Ia ada. Siapa memuji Allah, mengambil bagian dalam kebahagiaan mereka yang murni hatinya: ia mencintai Allah dalam iman, sebelum ia memandang-Nya dalam kemuliaan. Melalui doa pujian, Roh Kudus mempersatukan diri dengan roh kita, untuk menyaksikan bahwa kita adalah anak-anak Allah. ... pujian mencakup bentukbentuk doa yang lain dan membawanya menuju sumber dan tujuannya ...” (KGK art. 2639).

Doa pujian adalah bentuk doa yang secara langsung dilakukan oleh manusia sebagai pengakuan bahwa Allah adalah sumber hidup. Manusia menyadari sebagai anak-anak Allah serta memuliakan Allah dengan kerendahan hati. Manusia mengambil bagian dalam kebahagiaan dan kemuliaan-Nya.

Doa lisan merupakan unsur hakiki dalam kehidupan Kristen. Yesus Kristus tidak hanya mendoakan doa-doa liturgi dalam Sinagoga, tetapi seperti tertulis di dalam Kitab Suci, Yesus Kristus mengajarkan doa lisan kepada para murid-Nya sebagai gambaran, ungkapan bahwa Bapa-Nya yang ada di surga pun mendengarkan.

"Doa lisan merupakan unsur hakiki dalam kehidupan Kristen. Kristus mengajar murid-murid-Nya yang merasa tertarik pada doa batin dari Gurunya, satu doa lisan: Bapa Kami. Yesus tidak hanya mendoakan doa-doa liturgi dalam sinagoga, tetapi seperti yang ditunjukkan Injil kepada kita Ia sendiri mengangkat suara, mengucapkan doa pribadi-Nya. Doa-doa-Nya terbentang dari memuji Bapa dengan penuh gembira sampai kepada permohonan dalam sakratul maut di taman Getsemani." (KGK art. 2701).

Melalui Firman-Nya Allah berbicara kepada manusia, dengan doa lisan manusia mengungkapkan macam-macam doa melalui kata-kata, baik yang dipikirkan maupun yang diucapkan dengan sepenuh hati. Mello (1980: 101) mengatakan bahwa "doa lisan itu biasanya dijelaskan sebagai doa yang diucapkan” serta ungkapan orang beriman di hadapan Allah.

Doa renungan memiliki arti sama dengan doa meditasi yakni satu pencarian. Artinya satu pencarian supaya umat manusia memahami apa yang dikehendaki Allah pada dirinya. Dalam doa ini, misteri Kristus direnungkan dan dihayati, serta diolah terus sampai dapat mendalami persatuan manusia dengan 
Kristus. Doa renungan menjadi salah satu cara untuk mengartikan kehendak Tuhan atas diri manusia. Dalam doa renungan ini, Roh mencari kebenaran dan menjawab apa yang dikehendaki Allah sang pencipta. Caranya menggunakan buku-buku rohani sebagai panduan seperti Kitab Suci, buku renungan harian, tulisan Bapa-Bapa rohani, teks-teks liturgi, dan sebagainya.

Doa batin adalah doa seorang anak kepada Bapa-Nya. Dalam hal ini, anak memiliki arti sebagai seorang pendosa yang sudah diampuni serta menghendaki atas dirinya menerima cinta kasih dan membalasnya dengan ungkapan cinta kasih yang lebih besar lagi. Gereja memandang Yesus dengan penuh iman, mendengarkan Sabda Allah dan mencintai dalam misteri-Nya. Doa batin merupakan suatu anugerah dan rahmat Allah yang luar biasa. Dengan kontemplasi manusia memandang Yesus Kristus dan dengan penuh iman memandang misteri kehidupan Kristus dengan mencintai-Nya lebih sungguh dan mengikuti-Nya dengan lebih baik lagi.

\section{PAROKI SANTO HILARIUS KLEPU}

Stasi Klepu berlindung di dalam nama Sakramen Mahasuci. Gedung Gereja Sakramen Mahakudus terletak di lingkungan Genengan. Stasi Klepu terbagi menjadi 11 lingkungan, yaitu Lingkungan Klepu, Pondok, Sulingan, Wareng, Mendung, Tanjung, Ngapak, Genengan, Sambi Barat, Sambi Timur, Bendo. Jarak masing-masing lingkungan dengan gereja sebagai pusat kegiatan umat rata-rata sekitar 0,5 km hingga 6 km. Sejak tahun 1990 dibentuklah Dewan Gereja Klepu. Dewan Gereja ini dipercaya untuk mengelola pendampingan umat dan penanganan beberapa urusan administratif yang terkait dengan kehidupan Stasi. Ketua dewan saat itu adalah Bapak K. Pirnadi. Pada tahun 1993 - 1997, Bapak Edy Sudarman dipercaya mengantikan Bapak K. Pirnadi. Tahun 1997, istilah Dewan Gereja diganti menjadi Dewan Stasi. Periode tahun 1997 - 2000, jabatan ketua dipegang oleh Bapak Gimin. Periode tahun 2000 - 2007, jabatan dipegang oleh Bapak Petrus Sutarno. Sesudah itu, kepengurusan Dewan Stasi dipegang oleh kelompok “muda” dengan Bapak FX. Adi Suwito menjadi ketuannya (Wibowo, 2016: 1-3).

Sejak masih menjadi Stasi Ambarawa, pada tahun 1897, wilayah pelayanan stasi dari Madiun meliputi daerah Ponorogo, Pacitan, Magetan, dan Ngawi. Pada tahun 1928 sampai awal 1950 bangsa Indonesia menghadapi masa yang sulit. Bangsa Indonesia mengalami masa penjajahan dari tahun 19421945.Sejak tahun 1968, wilayah Gereja Katolik Stasi Sakramen Mahasuci-Klepu menjadi bagian dari Reksa pastoral di Paroki Santa Maria, Ponorogo. Wilayah ini terletak di pinggir hutan di daerah lembah yang membentang antara Bukit Mrican dan Pa'jaran yang menjadi deretan dari pegunungan Wilis, tepatnya di Kecamatan 
Sooko, Kabupaten Ponorogo. Luas wilayah 781, 867 ha berupa tegal dan 47, 125 ha dan berupa pemukiman penduduk.

Sejak April 2009, Stasi Sakramen Maha Kudus menjalani pembinaan dan pastoral secara intensif dan bertahap oleh RD. Skolastikus Agus Wibowo, Pastor Rekan Paroki St. Maria Ponorogo atas permintaan Pastor kepala Paroki St. Maria Ponorogo, RD Yuventius Fusi Nusantoro. Sejak tanggal 13 Januari 2010, Gereja Katolik Stasi Sakramen Maha Kudus diresmikan oleh Mgr. Vincentius Sutikno Wicaksono (Uskup Surabaya) menjadi Gereja Katolik Kuasi Paroki St. Hilarius, Klepu. Pada tanggal 13 Januari 2012, diresmikan menjadi Paroki oleh Mgr. Vincentius Sutikno Wicaksono (Wibowo, 2016: 4-5).

Dalam reksa pastoral di Paroki St. Hilarius Klepu, kegiatan pastoral yang ada yakni: pastoral anak (BIAK), pastoral remaja, pastoral OMK, pastoral keluarga dan pastoral lanjut usia (Lansia), yang diselenggarakan dan diagendakan dalam keseluruhan pada tahun 2016. Masing-masing bidang mempunyai kegiatan yang dilaksanakan, meskipun tidak banyak dan kegiatannya berbeda-beda namun sejauh ini masih tetap diadakan kegiatan untuk memantau dan membantu perkembangan iman umat di paroki St. Hilarius, Klepu (Wibowo, 2016: 5-6).

\section{HASIL PENELITIAN KEGIATAN DOA REMAJA KATOLIK (REKAT) DI PAROKI ST. HILARIUS KLEPU}

Penelitian ini merupakan penelitian kualitatif yang datanya diperoleh melalui pembagian instrumen yang berupa pertanyaan kepada Remaja Katolik di Paroki St. Hilarius Klepu untuk memperoleh gambaran mengenai Remaja Katolik dan Kegiatan doa Remaja Katolik di Paroki St. Hilarius Klepu.Metode kualitatif adalah suatu bentuk penelitian yang menghasilkan uraian data terdalam pada usaha menelaah dan memahami sikap, pandangan, perasaan, dan perilaku baik individu atau kelompok orang mengenai suatu fenomenologi atau kejadian tertentu (Moleong, 2005: 6).

Hasil data penelitian menunjukkan bahwa semua responden memahami atau mengerti apa itu doa. Menurut REKAT, doa adalah cara berkomunikasi atau bercakap-cakap kepada Allah, dengan menjalin relasi serta mengucapkan syukur dan memusatkan perhatian kepada Tuhan. Adapun yang mendorong REKAT untuk berdoa, yang utama adalah kesadaran untuk bertobat dengan mengucapkan syukur kepada Tuhan kemudian menyampaikan permohonan/intensi supaya semakin dekat dengan Tuhan serta memohon bantuan-Nya agar diberikan kesehatan.

Doa dilaksanakan setiap saat (dalam waktu yang berbeda-beda seperti waktu siang hari, saat doa Malaikat Tuhan atau Ratu surga, ketika mau tidur, bangun tidur, mau makan) dan setiap hari. Doa dapat dilakukan ditempat-tempat ibadah untuk membantu umat Kristiani agar berdoa lebih khusuk dan nyaman. 
Doa memiliki model yang berbeda-beda diantaranya; doa berkat, doa penyembahan, doa permohonan, dan doa syukur. Dalam pelaksanaannya bisa pada saat mau ulangan, mau berangkat sekolah, diutus, kesehatan, pertobatan, dan atas karunia. Kemudian REKAT juga memiliki bentuk doa yang berbeda-beda diantaranya doa lisan dan doa renungan. Selanjutnya, doa yang sering dilakukan dikelompokkan menjadi dua yakni rumusan baku atau lisan dan doa untuk pribadi atau renungan.

Adapun hal yang menarik dalam kegiatan doa, REKAT memiliki rasa senang bisa berkumpul dengan teman sebaya serta memiliki rasa kebersamaan. Adapun alasannya dapat dikelompokkan menjadi tiga bagian; relasi dengan Tuhan, relasi dengan teman, dan bisa mengembangkan potensi diri. Manfaat doa bersama dikelompokkan menjadi tiga bagian: Pertama "untuk sesama" bisa berkumpul, lebih terbuka, kebersamaan. Kedua "untuk Tuhan” supaya lebih dekat dengan Tuhan, mengenal Tuhan, beban hati hilang. Ketiga "untuk mengembangkan potensi diri” berani mengajak berdoa, punya pengalaman, bertambah wawasan, dan bisa memimpin. Ketika REKAT melaksanakan doa, ada faktor-faktor yang menghambat. Faktor penghambat tersebut dikelompokkan menjadi dua bagian yakni Faktor Internal diantaranya malas, lelah, lupa, sibuk, sakit dan Faktor Eksternal ialah pengaruh IPTEK.

Remaja Katolik (REKAT) mendefinisikan dirinya adalah berusia remaja atau Sekolah Menengah Pertama, yang sudah dibaptis sehingga meningkatkan kedewasaan iman dengan pembinaan dan pendampingan secara terus menerus. REKAT berpartisipasi dalam Tiga Tugas Kristus (menguduskan, mewartakan, dan mengembalakan). Partisipasi REKAT dalam tritugas Kristus adalah tugas menguduskan (berdoa). Dengan berdoa REKAT memiliki rasa kekompakkan melalui kumpul bersama, berani memimpin doa bersama, bahkan dalam doa juga dapat menunjuk atau menentukan giliran berdoa.

Kegiatan yang pernah dilaksanakan REKAT berdasarkan tiga tugas Kristus sebagai Imam yakni ikut Misa harian, Novena, Koor, Doa bersama, Mazmur dan Latihan Misdinar, sebagai Nabi yakni kegiatan Rekoleksi, kemudian tugas Raja yaitu kegiatan membawa Obor. Berdasarkan pengalaman selama mengikuti kegiatan, REKAT semakin memiliki banyak teman (relasi pada teman) dan dapat mengembangkan potensi diri.

Makna dari kegiatan tersebut, REKAT mampu terlibat dalam tiga tugas Kristus diantaranya tugas Imam yang diharapkan untuk lebih dekat dengan Tuhan. Kemudian melalui tugas seorang Raja dapat dilihat dari hidup sosial, kunjungan, dapat berbagi kasih, serta pelayanan kepada Allah.

Adapula faktor penghambat kegiatan berdoa bersama yang dapat dikelompokkan menjadi 2 bagian. Faktor internal diantaranya kecenderungan memiliki rasa malas, dalam kegiatannya pun kurang serius. Kemudian faktor 
eksternal berupa pengaruh IPTEK. Ini merupakan masalah yang serius dimana dari tiap masing-masing kendala tersebut harus diperhatikan bersama.

Meskipun ada faktor penghambat tersebut, ada cara mengatasinya. Ada 1 responden mengatakan dengan berdoa pribadi, serta ada 1 reponden mengatakan membuat jadwal pribadi. Satu reponden mengatakan dipercepat waktu doa bersama, 6 responden mengatakan menegur, 1 reponden mengatakan mengajak atau mendatangi teman-teman.

\section{KESIMPULAN}

Remaja Katolik (REKAT) sudah melaksanakan kegiatan doa bersama di Paroki St. Hilarius Klepu secara rutin setiap Minggu pada hari Rabu jam tujuh malam (19:00 WIB). Sedangkan prakteknya bertempat di Aula Paroki sebagai tempat untuk pendampingan serta pembinaan bersama. Dengan cara berkumpul bersama, kemudian salah satu teman ada yang memimpin dengan harapan berani memimpin doa bersama, bahkan dalam doa dapat menunjuk atau menentukan giliran berdoa untuk minggu depan.

Dalam pelaksanaannya, REKAT memiliki manfaat yaitu dekat dengan Tuhan, merasa senang karena bisa berkumpul bersama dengan teman sebaya dan dapat mengembangkan potensi diri. Dengan faktor pendukung tersebut membuat mereka berani mengajak berdoa dan bisa memimpin doa. Ada faktor penghambat untuk berdoa yaitu rasa malas, lelah, lupa, sibuk, sakit dan pengaruh IPTEK. Meskipun ada faktor penghambat REKAT memiliki faktor pendukung yaitu dengan berdoa pribadi, membuat jadwal pribadi, mempercepat waktu doa bersama, menegur dan mendatangi teman-teman dan mengajak untuk berdoa.

\section{DAFTAR PUSTAKA}

1995. Katekismus Gereja Katolik. Flores: Nusa Indah.

. 2006. Kitab Hukum Kanonik. Jakarta: Konferensi Waligereja Indonesia. 2008. Dokumen Konsili Vatikan II. Jakarta: OBOR.

. 2011. Alkitab Deuterokanonika. Jakarta: Lembaga Alkitab Indonesia.

2002. Pedoman Umum Misale Romawi. Flores: Nusa Indah.

Beek, Van Aart. Martin. 1987. Konseling Pastoral Sebuah Buku Pegangan Bagi Para Penolong Di Indonesia. Pencetakan SW: Jakarta.

Abineno, J.L.Ch. 2004. Doa Menurut Kesaksian Perjanjian Baru. Jakarta: BPK Gunung Mulia.

Mello, de Anthony. 1980. Sadhana. Yogyakarta: Kanisius. 
Ardijanto, D. B. Karnan.2009. Dasar Pelayanan dan Tujuan Pelayanan Pastoral Gereja. Jurnal Pendidikan Agama Katolik (Volume 1). Madiun: Widya Yuwana.

Arikunto, Suharsimi. 2002. Prosedur Penelitian Suatu Pendekatan Praktek. Jakarta: Penerbit Rineka Cipta.

Beding, Bosko. 1989. Ibu Teresa Karya dan Orang-orangnya. Ende: Nusa Indah.

Darmawijaya, St. 1994. Mengarungi Hidup Berkeluarga. Yogyakarta: Kanisius.

Dhavamony, Mariasusai. 1995. Fenomenologi Agama. Yogyakarta: Kanisius.

Fowler, James W. 1995. Teori Perkembangan Kepercayaan. Yogyakarta: Kanisius.

Gunarsa, Singgih D. 2008. Psikologi Perkembangan Anak dan Remaja. Jakarta: BPK Gunung Mulia.

Hetu, Inocens Ruben. 2007. Tahap-Tahap Doa Kodrati Seri Pengalaman Mistik St. Teresa Avila. Yogyakarta: Kanisius.

Hidayat, A. A. A. 2017. Metodologi Penelitian Ilmu Keperawatan Praktis Ed. 4. Jakarta: Salemba Medika.

Hurlock, Elisabeth B. 1992. Perkembangan Anak (Edisi Keenam). Jakarta: Erlangga.

Jacobs, Tom. 2004. Teologi Doa. Yogyakarta: Kanisius.

Martasudjita, Emanuel. 1999. Liturgi Pengantar untuk Studi \& Praksis Liturgi. Yogyakarta: Kanisius.

Moleong, Lexy J. 2005. Metode Penelitian Kualitatif. Rosda: Bandung.

Nadeak, Wilson. 1991. Memahami Anak Remaja. Yogyakarta: Kanisius.

Patilima, Hamid. 2013. Metode Penelitian Kualitatif. Bandung: Penerbit Alfabeta.

Sene, Alfons. 1987. Kita Berkatekese demi Remaja. Bandung: Nusa Indah.

Shelton, Charles. M. 1993. Moralitas Kaum Muda. Yogya: Kanisius.

Sparough, Michael J \& Beckman. 2009. Bunda Maria, Dominikus dan Ignatius berdoa dengan Tubuh. Yogyakarta: Kanisius.

Stefanus Tay dan Ingrid Listiati Tay. 2016. Maria O Maria, Bunda Allah, Bundaku, Bundamu. Surabaya: Murai Publishing.

Supriyadi, Agustinus. 2017. Membangun Semangat Kerasulan Remaja Katolik dalam Konteks Masyarakat Pluralis di Indonesia."dalamJurnal Pendidikan Agama Katolik (Volume 17). Madiun: Widya Yuwana.

Surinono, Chris. 2015. Doa Batin Bersama St. Teresa dari Avila. Yogyakarta: Kanisius.

Tondowidjojo, John. 2001. Sejarah Perkembangan Keuskupan Surabaya. Surabaya: Sanggar Bina Tama.

Keuskupan Surabaya, Seketariat. nd. Arah Dasar Keuskupan Surabaya 2010-2019 Bidang Pembinaan (Formatio) seri DPK 05.01.00. Surabaya 
Van. Hooijonk, P.1980. Pengertian Pastoral (Seri Pastoral No. 26). Jogjakarta: Pusat Pastoral.

Wibowo, Skolastickus Agus. 2016. Profil Paroki. Karya Tidak Diterbitkan.

Widagdo, Th. Aq. \& M. Rochadi. 2003. Meditasi Itu Keheningan (pedoman praktis berdoa). Yogyakarta: Kanisius.

Widyaningsih, Bernadeta Dhaniswara. 2011. "Permasalahan Remaja dan Lingkungan Sekolah Katolik. "Dalam Jurnal Pendidikan Agama Katolik (Volume 6). Madiun: Widya Yuwana. 